\title{
Distribution of 1990s Income Gains
}

\section{Dean Parham, Paula Barnes, Paul Roberts and Sharon Kennett}

\begin{abstract}
A ustralia was one of only a few high-income countries to experience faster growth in the 1990s than in the 1980s (OECD, 2001). Australia's performance was quite impressive on a number of counts, even in the face of external shocks (most notably the Asian economic crisis). The 1990s brought:
\end{abstract}

- nine years of continuous GDP growth averaging over 4 per cent - the longest period since the early 1970 s;

- a decline in unemployment from the recession-affected rates of the early 1990s; and

- falls in inflation to rates not seen since the early 1970 s.

The OECD (2001) found in its study of 1990s growth patterns that two features distinguished the better-performing countries: improved productivity growth and greater labour utilisation (the rate at which the population is actively engaged in market-based work).

Particularly on productivity, Australia rated highly. Multifactor productivity growth accelerated from an average of 0.6 per cent a year in the 1970s and 1980s to an average of 1.7 per cent a year in the 1990s (Parham and Kennett, 2001). The acceleration from 0.6 to 1.7 per cent a year is based on ABS estimates over peakto-peak productivity cycles. There is further evidence of an acceleration of one percentage point or more in an ABS trend productivity series, in comparisons between business cycles and in econometric analysis (Parham and Kennett, 2001).

The productivity surge promoted strong growth in average income. Faster productivity growth accounted for over 90 per cent of the acceleration in average incomes from 1.4 per cent a year in the 1970s and 1980s to 2.5 per cent a year in the 1990s (Parham et al., 2000).

The limitations in using average income as a welfare measure are well known. Nevertheless, the magnitude of the increase is of some significance, suggesting that, as a whole, Australians developed a lot more wherewithal to finance consumption, save and invest for the future, and contribute to at least some social and environmental goals. The additional productivity growth in the 1990s provided an additional average income of $\$ 2700$ per person or $\$ 7000$ per household (Banks, 2001).

The authors are members of staff of the Productivity Commission. The views expressed in this paper are those of the authors and do not necessarily reflect those of the Productivity Commission. 
But it is also commonly argued that the distribution of income and not just average income matters for community welfare. In the 1990s context, a number of commentators have expressed concern that many Australians have been stranded by economic developments. Other concerns include whether the income gains have come at some cost in terms of lifestyle, community cohesion and environmental harm.

This paper looks at only part of the distributional picture. In particular, it examines the functional distribution of income - that is, between labour and capital. It finds that the productivity and income gains of the 1990s have been distributed evenly between labour and capital. Labour has gained from higher real wages and improved employment outcomes. Capital has earned higher profits. It appears that increased competitive pressures may have been a factor, not only in generating productivity gains, but also in ensuring that, at least at a broad level, the gains were not retained in 'excessive' growth in profits. Consumers and commercial users have benefited from many of the productivity gains being passed on through lower prices. The paper also makes some observations on the personal and household distribution of income, based on other studies.

\section{Distribution of the 1990s Aggregate Income Gains}

There has been worldwide interest in the income distribution effects of factors, such as lower trade barriers and technological change, that enhance productivity growth. Interest commonly focuses on whether productivity-enhancing changes are factor-neutral or introduce a bias against labour, in general, or against a certain type of labour - particularly, unskilled workers. All other things equal, a bias would show up in lower rates of employment or the payment of lower wages, at least in relative terms. Either way, a bias would lead to a relative (if not absolute) decline in total payments to labour or to the labour type.

A number of developments could have enhanced productivity growth in Australia in the 1990s and, at the same time, could have altered the distribution of income between labour and capital. The possibilities include:

- technological change - some technologies are considered to be labour saving and some are considered to favour skilled labour, the increased use of information and communications technologies being a major case in point;

- reductions in trade barriers - some claim that competition from low-wage countries reduces the wage and employment prospects of low-skilled workers;

- a shift towards enterprise bargaining - there are claims that decentralisation of wage determination and associated changes have reduced the relative bargaining strengths of workers;

- the introduction of a stronger commercial focus for government business enterprises and competition in their markets - this gives enterprises incentives to reduce excess manning levels that may have built up in the past under an 'employer of last resort' philosophy; and 
- contracting out - there are claims that contracting out reduces costs, frequently at the expense of lower wages, if not reductions in employment.

The general tenor of these claims implies that important economic changes in the 1990s have introduced biases against labour — and perhaps especially against unskilled labour. All other things equal, this would be evident in a reduction in the proportion of income distributed to labour.

The labour income share - wage and salary payments to labour as a proportion of total factor income - provides a convenient measure to track the distribution of income to both labour and capital. Movements in the capital share can be taken to be equal (but opposite) to movements in the labour share. (Capital income is the gross operating surplus before depreciation, interest and tax.)

Figure 1 shows the evidence. It reveals that there was no bias against labour at the aggregate level during the 1990s. The economy-wide labour income share was stable from the late 1980s and right through the 1990s, indicating that labour and capital shared proportionately in the strong income growth of the 1990s. (The higher labour income share in the 1970s and 1980s is discussed in a later section.)

\section{Figure 1: Economy-wide Labour Income Share, Real Product} Wage and GDP per Labour Hour, 1964-65 to 1999-00

Index 1997-98 = 100 (LHS) and per cent (RHS)

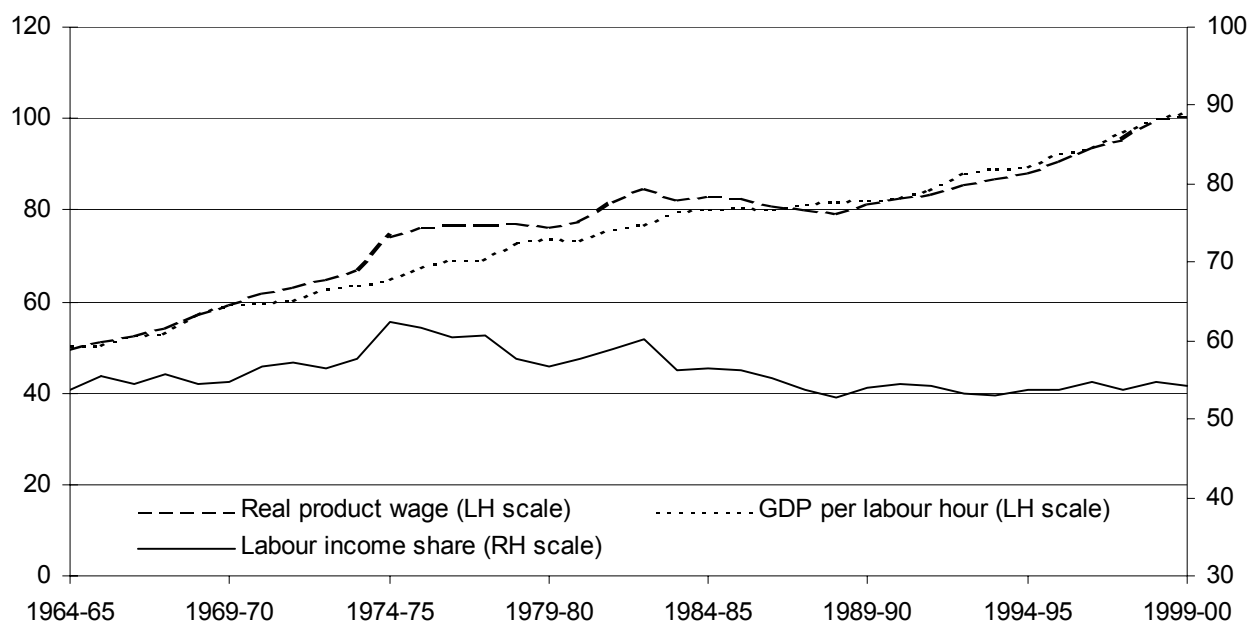

Data source: Estimates based on ABS data. 
Wage and profit rates

Changes in the labour income share can be related mathematically to productivity and wage growth. Doing so introduces an explicit link to productivity growth and its distribution through rates of payment to factors of production. Formally, as shown in Parham et al. (2000) growth in the labour income share is equal to:

- $\quad$ growth in the real product wage ${ }^{1}$ (the average nominal hourly wage, deflated by an index of product prices - the GDP deflator in this case); less - $\quad$ growth in labour productivity (as represented in the economy-wide case by GDP per hour worked).

An array of real wage and labour productivity outcomes is therefore consistent with a stable labour income share. The only requirement is that growth in real wages must match labour productivity growth.

Figure 1 shows the strong productivity growth that characterised the 1990s. Because the growth in real wages matched the strong labour productivity growth, there was no substantial movement in the labour income share. The actual growth rates are shown in Table 1 (as reported in Parham et al. (2000), there was zero growth in the factor income shares from 1990-91 to 1998-99).

The same can be shown on the capital side. The real rate of payments to capital increased, but by no more than the increase in capital productivity, thus essentially preserving the capital income share (Table 1).

This examination of the distribution of factor income is from a producer cost point of view. The use of the output price deflator is crucial to this view. The stability in the factor shares means that there was no change in the efficiency costs of employing labour and capital. Increases in the real costs of employing both factors of production were matched by increases in their productivity.

But it is also possible to view these results from an 'income received' perspective. From that perspective, those in employment received sufficient of the productivity gains through real wage increases to maintain their share in total income.

Real wages as a source of income are normally computed with a consumption price deflator - the CPI. The so-formed 'real consumption wage' also shows growth in the 1990s, although a divergence in growth between consumption and producer prices means that the real consumption wage did not grow as strongly as the real product wage (Table 1).

On the capital side, the rate of gross profit grew at over 1 per cent a year in the 1990s (Table 1), increasing from an average of 13.9 to 15.4 per cent.

1 The concepts of the real product wage and the real consumption wage are explored by Blanchard (1997). 
Table 1: Accounting for Growth in Factor Income Shares, 1990-91 to 1999-00

Per cent per year

\begin{tabular}{lc}
\hline $\begin{array}{l}\text { Growth in labour income share } \\
\quad \text { equals }\end{array}$ & -0.1 \\
Growth in real product wage & 2.2 \\
$\quad$ less & 2.3 \\
Growth in labour productivity & \\
Information item: & 1.7 \\
Growth in real consumption wage & 0.1 \\
$\quad$ equals & 1.2 \\
$\quad$ Growth in real profitability & less \\
Growth in capital productivity & 1.1 \\
Information item: & \\
Growth in rate of profit & 1.1 \\
\hline
\end{tabular}

Source: Estimates based on ABS data.

\section{The 1970s and 1980s Experience}

The elevated labour income share in the 1970s and 1980s stands out in Figure 1 and belies the 'stylised fact' that factor income shares remain largely invariant. A review of history and the factors underlying the increase in the labour income share and its subsequent decline serves, by way of contrast, to reinforce what went 'right' in the 1990s.

Like many other economies, the Australian economy was hit by a number of shocks in the mid-1970s. There was a sharp decline in the terms of trade and a reduction in export volumes. On the supply side, real wages climbed sharply, but there was no accompanying productivity increase. The issue in this period was not about the distribution of strong productivity growth, but whether a wage 'push' could be accommodated.

The labour income share rose sharply from 1972-73 to 1974-75 as the increase in the real product wage outstripped the growth in labour productivity (Figure Error! Not a valid link.). The divergence between wage growth and productivity growth became known as 'the real wage overhang'.

The labour income share rose by over 5 per cent a year over these two years, with increases in the real product wage of 7 per cent a year (Table 2). The higher real cost of employing labour, without a commensurate increase in productivity 
and therefore income, squeezed profits. Producers had an inducement to substitute capital for labour.

Table 2: Accounting for Growth in the Labour Income Share

\begin{tabular}{|c|c|c|c|c|c|c|}
\hline \multicolumn{7}{|c|}{ Per cent per year } \\
\hline & $\begin{array}{c}1964 / 65 \\
\text { to } \\
1972 / 73\end{array}$ & $\begin{array}{c}1972 / 73 \\
\text { to } \\
1974 / 75\end{array}$ & $\begin{array}{c}1974 / 75 \\
\text { to } \\
1983 / 84\end{array}$ & $\begin{array}{c}1983 / 84 \\
\text { to } \\
1988 / 89\end{array}$ & $\begin{array}{c}1988 / 89 \\
\text { to } \\
1993 / 94\end{array}$ & $\begin{array}{c}1993 / 94 \\
\text { to } \\
1999 / 00\end{array}$ \\
\hline \multicolumn{7}{|l|}{ Economy-wide } \\
\hline $\begin{array}{l}\text { Growth in labour income } \\
\text { share }\end{array}$ & 0.6 & 5.2 & -1.2 & -1.3 & 0.1 & 0.3 \\
\hline \multicolumn{7}{|l|}{ equals } \\
\hline $\begin{array}{l}\text { Growth in real product } \\
\text { wage }\end{array}$ & 3.4 & 7.1 & 1.1 & -0.7 & 1.8 & 2.5 \\
\hline \multicolumn{7}{|l|}{ less } \\
\hline $\begin{array}{l}\text { Growth in GDP per labour } \\
\text { hour }\end{array}$ & 2.8 & 1.8 & 2.3 & 0.6 & 1.7 & 2.2 \\
\hline \multicolumn{7}{|l|}{ which equals } \\
\hline \multicolumn{7}{|l|}{ less } \\
\hline & \multicolumn{5}{|c|}{ less } & -0.2 \\
\hline $\begin{array}{l}\text { Growth in the workforce } \\
\text { less }\end{array}$ & & 1.7 & 2.8 & 1.3 & 1.7 \\
\hline $\begin{array}{l}\text { Growth in the employment } \\
\text { rate }\end{array}$ & -0.3 & -0.1 & -1.0 & 0.5 & -0.6 & 0.7 \\
\hline \multicolumn{7}{|l|}{ Information items: } \\
\hline $\begin{array}{l}\text { Growth in real consumption } \\
\text { wage }\end{array}$ & 4.3 & 8.4 & 1.0 & -1.0 & 1.0 & 1.7 \\
\hline Growth in rate of profit & -2.1 & -11.4 & 0.8 & 1.5 & 0.4 & 0.7 \\
\hline \multicolumn{7}{|l|}{ Market sector } \\
\hline $\begin{array}{l}\text { Growth in labour } \\
\text { productivity }\end{array}$ & 2.4 & 4.2 & 2.1 & 1.5 & 2.1 & 3.1 \\
\hline equals & & & & & & \\
\hline $\begin{array}{l}\text { Capital deepening } \\
\text { plus }\end{array}$ & 1.5 & 1.9 & 1.4 & 0.5 & 1.5 & 1.4 \\
\hline $\begin{array}{l}\text { Multifactor productivity } \\
\text { growth }^{\mathrm{a}}\end{array}$ & 0.9 & 2.4 & 0.7 & 1.0 & 0.6 & 1.7 \\
\hline
\end{tabular}

a Except for the period 1993-94 to 1998-99, the displayed rates of MFP growth should not be interpreted as underlying or trend rates of growth.

Source: Estimates based on ABS data. 
The higher labour income share was not sustained. In fact, there was a very drawn-out readjustment. The labour income share gradually declined from the mid-1970s as further growth in the real wage moderated and growth in labour productivity picked up. However, labour productivity growth picked up through an undesirable source - growth in unemployment (Figure 2). The relatively high cost of labour would have contributed some 'classical' unemployment due to capital-labour substitution. But weakness in aggregate demand would have also been a major factor. Whatever its cause, higher unemployment was consistent with a higher ratio of output to hours worked - that is, higher labour productivity.

This mechanism is illustrated in Table 2 with a decomposition of growth in labour productivity (GDP per labour hour). The employment rate declined by one per cent a year from the mid-1970s to the mid-1980s, even with slower growth in workforce numbers (growth in the workforce, combined with a decline in the employment rate, means that unemployment increased). The faster rate of decline in the employment rate over 1974-75 to 1983-84, compared with the previous period (from -0.1 to -1.0 per cent a year), more than accounts for the 0.5 of a percentage point acceleration in labour productivity between the two periods. The decline in the employment rate and the increase in the unemployment rate are also shown in Figure 2.

The labour income share then continued its readjustment, but through a different mechanism. The prices and incomes Accords in the 1980s brought reductions in real wages. The real product wage declined by 0.7 per cent a year from 1983-84 to 1988-89. This contributed more than substantially to the reduction in the labour income share of 1.3 per cent a year. Labour productivity growth was a slow 0.6 per cent a year. The labour income share returned to around 1960s levels by the late 1980s (Figure 1).

Strong multifactor productivity (MFP) growth distinguishes the 1990s — and the 1960s - from the mid-1970s to the end of the 1980s (see 'market sector' section of Table 2). Strong MFP growth in the 1990s sustained the increases in real wages through strong labour productivity growth. ${ }^{2}$ As a result, the increased real cost of labour did not squeeze profits. Real wages and rates of profit both increased. And, with strong growth in output, employment grew and unemployment fell - after the major disruption of the early 1990s recession (Figure 2). Labour benefited from both higher real wage rates and higher employment rates. The distribution of income between labour and capital remained even.

The experience of the past three decades illustrates that productivity growth is essential to sustain increases in real wages and employment. Without commensurate productivity growth, a wage 'push' can contribute to unemployment and to a drawn-out and costly period of adjustment.

2 As is implied in Table 2, growth in labour productivity is equal to capital deepening (growth in the capital-labour ratio weighted by the capital income share), plus growth in multifactor productivity. Multifactor productivity is calculated for the market sector and not for the economy as a whole (see text next page). 


\section{Figure 2: Workforce Unemployment Rate and Working-age Employment Rate, 1964-65 to 1999-00}

Per cent

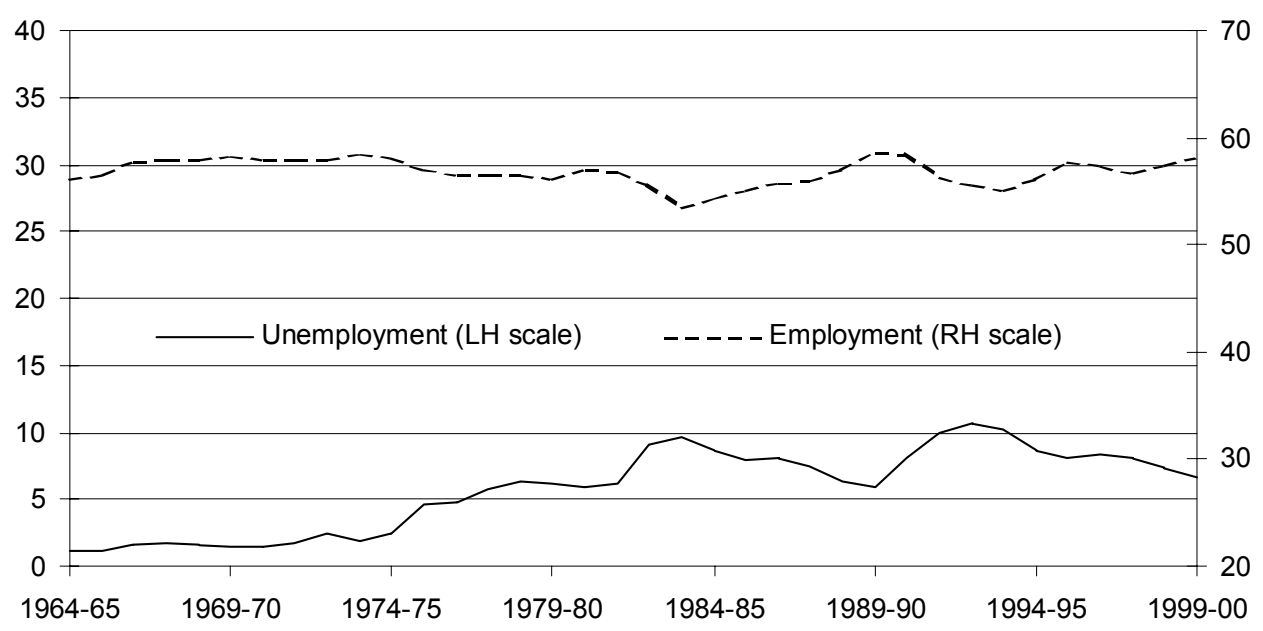

Data source: ABS Labour Force Statistics database on EconData.

\section{Industry Perspective}

Whilst there was little or no bias against labour at the economy-wide level in the 1990 s, there was a slight bias against labour in the market sector of the economy. The market sector covers around 60 per cent of the measured economy, but excludes service activities (such as public administration, defence, health and education) that do not have sufficiently well-measured outputs to include in productivity calculations. There was a small reduction in the labour income share in the market sector of 0.3 per cent a year from 1990-91 to 1999-00 (Table 3). In other words, production in the market sector became slightly more capitalintensive. (As can be seen from Table 3, the experience of individual industries differed, with the labour income share decreasing in some industries, but increasing in others.)

However, the essentially stable share for the economy as a whole implies that the slight bias against labour in the market sector has been mostly offset by a slight bias in favour of labour in the non-market sector. For example, the strong employment growth in business services could have been one offsetting development. $^{3}$

3 There were insufficient data to examine the direction of distributional biases in the non-market sector. 
Table 3: Growth in Labour Income Shares, by Market Sector Industry, 1990-91 to 1999-00

\begin{tabular}{lccc}
\multicolumn{4}{c}{ Per cent per year } \\
\hline $\begin{array}{l}\text { Real product } \\
\text { wage }\end{array}$ & $\begin{array}{c}\text { Labour } \\
\text { productivity }\end{array}$ & $\begin{array}{c}\text { Labour income } \\
\text { share }\end{array}$ \\
\hline Agriculture & 5.1 & 3.0 & 2.1 \\
Mining & 4.0 & 6.3 & -2.1 \\
Manufacturing & 1.5 & 2.6 & -1.1 \\
Electricity, gas \& water & 1.0 & 4.0 & -3.0 \\
Construction & 0.6 & 0.5 & 0.2 \\
Wholesale trade & 5.9 & 5.1 & 0.8 \\
Retail trade & 1.8 & 1.3 & 0.5 \\
Accommodation, cafes \& & & & 0.2 \\
restaurants & 0.1 & -0.1 & -0.5 \\
Transport \& storage & 2.2 & 2.7 & -2.7 \\
Communication services & 4.3 & 7.2 & -1.3 \\
Finance \& insurance & 3.8 & 5.1 & 0.5 \\
Cultural \& recreational & & & -0.3 \\
services & -0.8 & -1.3 & \\
Market sector & 2.1 & 2.4 & \\
\hline
\end{tabular}

Source: Estimates based on ABS data.

The industry perspective also allows closer examination of the distribution of productivity gains through higher wages or higher profits or, with lower costs, through lower prices charged for goods and services produced. ${ }^{4}$ In the latter case, it is industrial and household purchasers who gain.

Figure 3 ranks industries in terms of their MFP growth in the 1990s. Wage, profit and price outcomes are also displayed in the same industry order.

\footnotetext{
4 It is possible to examine relative prices at the industry level and their association with relative productivity growth. This abstracts from the multitude of policy and other factors that determine the aggregate price level.
} 
Figure 3: Average Growth in Multifactor Productivity, Real Consumption Wage, Rate of Profit and Price ${ }^{\mathrm{a}}$, Industry Sectors, 1988-89 to 1999-00

Per cent per year

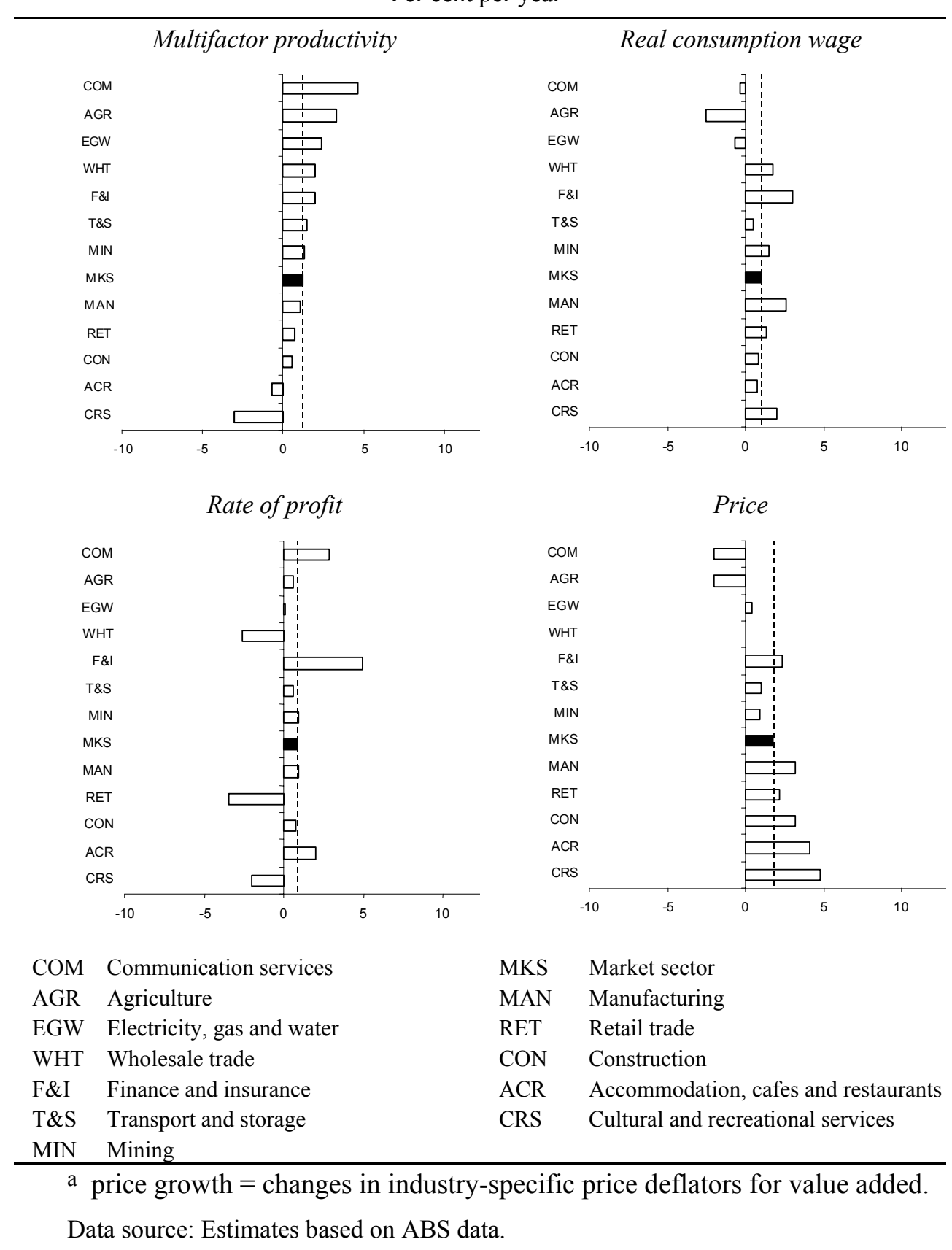


The relatively high productivity growth industries did not pay higher wage rises. In fact, there was relatively little variation in wage growth across industries, except for the aberration in Agriculture. There was wider variation in profit growth but no strong pattern consistent with productivity growth.

The strongest pattern is in price growth, which is negatively correlated with productivity growth. The high productivity growth industries had lower price increases and, in some cases, had price decreases.

These results are summarised in the correlation coefficients in Table 4. The strong negative correlation between productivity and prices $(-0.9)$ is confirmed. The size and the sign of the correlation between productivity growth and wage growth appears somewhat spurious, driven in particular by the negative wage growth in Agriculture.

Table 4 also shows an earlier period from the mid-1970s and through the 1980s. This period shows stronger correlation with profits (principally in Communication services and Electricity, gas \& water, as governments set firmer commercial targets for their business enterprises), but weaker correlation with prices.

Table 4: Correlation Coefficients Between Sectoral Multifactor Productivity Growth And Sectoral Growth in Wages, Profits and Prices

\begin{tabular}{lccc}
\hline & $\begin{array}{c}1974-75 \\
\text { to } 1988-89\end{array}$ & $\begin{array}{c}1988-89 \\
\text { to } 1999-00\end{array}$ & $\begin{array}{c}1974-75 \\
\text { to } 1990-00\end{array}$ \\
\hline Real consumption wage & 0.55 & -0.49 & 0.49 \\
Rate of profit & 0.75 & 0.37 & 0.69 \\
Prices & -0.57 & -0.90 & -0.83 \\
\hline
\end{tabular}

The correlations for the two periods indicate that, while productivity growth is important for growth in the general levels of real wages and profitability, industry variations in productivity growth have not translated nearly as readily into wage and profit growth differentials across industries. Industries with high productivity growth have not systematically raised wages by more than other industries. Industries with high productivity growth have paid the going wage increases, taken a little extra in profits in some cases (after weathering declines through the 1970s and early 1980s) but, mostly, have lowered their prices relative to other industries.

Moreover, the trend toward passing productivity gains on through lower prices has been stronger in the 1990s than in the past. This is consistent with producers facing stronger competitive pressure in the 1990s.

Competitive pressures thus appear to be important not only in contributing to the generation of productivity gains by sharpening incentives to be more 
productive (PC, 1999), but also in influencing the distribution of the gains. Competitive pressures are likely to have put some brake on nominal wage increases and profit growth, and to have encouraged productivity gains to be passed on through lower prices.

\section{Other Distributional Dimensions}

The distribution of productivity and income gains between labour and capital is only part of the complete distributional picture. However, mapping the functional distribution of income to the distribution of personal and household income is beyond the scope of this paper. Rather, the results of other studies are used to fill in some of the gaps.

The available evidence suggests that, while the distribution of income between labour and capital has been even, the distribution of earnings among individuals has become more unequal in the 1990s. The increase, however, is a continuation of the growth in earnings inequality during the 1980s, rather than a step up in the 1990s (Norris and McLean, 1999).

Other studies provide evidence of a bias in the growth in labour payments in favour of skilled workers. Their share of the total wage bill has risen from around 37 per cent in the mid-1980s to around 42.5 per cent in the late 1990s. Most of this increase took place in the 1990s. The evidence from Australian and overseas studies finds that technological change (especially computer related) is a source of bias in favour of skilled workers, but trade liberalisation appears to have little direct effect (de Laine, Laplagne and Stone, 2000).

Moreover, the change in the distribution of payments to labour does not appear to be the result of a change in the wage premium for skill. The growth in payments to skilled labour appears to be due more to faster growth in employment (relative to unskilled workers) than to faster growth in wages (de Laine, Laplagne and Stone, 2000).

There is evidence of faster wage growth for some individual occupation groups. For example, the salaries of chief executive officers increased at more than double the rate of average earnings over the decade to 1998 (Kryger, 1999). But, since chief executive officers only represent a small proportion of the working population, the effect on overall wage dispersion is likely to be small.

Ann Harding and others at the National Centre for Social and Economic Modelling (NATSEM, 2000) have investigated the dispersion in earnings at the personal and household level and the effects of government redistribution policies operating through the tax and transfer system. Both earned income (wages, salaries and self-employment income) and market income (earned income plus investment and superannuation income) became more unequal in the 1990s, compared with the early 1980s (Table 5). However, government transfers (pensions, allowances and other welfare payments) have reduced both the level of and growth in inequality in market income. Gini coefficients for gross income (market income plus transfers) show the effect of transfers and Gini coefficients 
for disposable income (gross income less income tax) show the effect of income tax.

Table 5: Gini Coefficient Measures of Inequality in the Distribution of Income $^{\mathrm{a}}$

\begin{tabular}{lcr}
\hline & 1982 & $1996-97$ \\
\hline Earned income & 0.477 & 0.538 \\
Market income & 0.457 & 0.511 \\
Gross income & 0.386 & 0.398 \\
Disposable income & 0.337 & 0.346 \\
\hline
\end{tabular}

a A higher Gini coefficient indicates greater income inequality. Measured for income units (groups of persons within households whose command over income is assumed to be shared).

Source: NATSEM (2000).

Importantly, the distribution of disposable income amongst individuals and households has remained relatively stable between the early 1980s and the mid1990s, despite the increased inequality in market incomes. This implies that the tax and transfer system has been largely effective in counteracting the increased inequality in market incomes.

However, middle-income earners have not shared equally in the income gains. Income earners at the top and bottom have both received more income, while middle income earners have missed out (NATSEM, 2000).

Whilst the NATSEM results refer to the period up to the mid-1990s, the ABS (2001) found that since then income distribution has not changed significantly.

Parham et al. (2000) provided some other distributional information. Governments have shared proportionately in the income gains of the 1990s through their revenue raisings, whilst there is a mixed picture in terms of the distribution of gains between urban and rural and regional communities. The data also suggest that foreigners did not receive a greater share of the 1990s income gains.

Finally, passing on productivity gains through lower prices is likely to have had its own distributional effects. For example, lower relative prices for goods and services that form a prominent part of expenditure in low-income households would be of greater benefit to low-income households.

General equilibrium or indirect effects also have distributional consequences. Earlier research by the Industry Commission (1996) into the effects of price changes for electricity and other utility services found that, even where the narrowing of cross subsidies increased prices to households, most households - 
including those with lower incomes - benefited overall, when the indirect effects through lower business costs were factored in.

\section{Concluding Remarks}

This paper has not taken a view on what the appropriate distribution of income might be. But it has presented evidence to suggest that the distributional consequences of the 1990s productivity and income gains have either been relatively benign or have been counteracted by policy measures.

The paper has shown that the strong income growth due in large part to a surge in productivity growth in the 1990s has been distributed evenly between labour and capital.

There has been little or no bias against labour at the aggregate level, despite a number of developments that are sometimes perceived to have an anti-labour bias. This does not mean that there have not been biases against labour in specific areas. Indeed, some such areas have been identified - at the industry level and in terms of skill level. But specific areas of bias against labour cannot be extrapolated. The economy has been operating in such a way that a bias against labour in one area has been counteracted by a bias in favour of labour in another area.

Other studies have provided evidence of increased dispersion in earnings in the 1990s, following on from trends emerging in the 1980s. However, the tax and transfer system has been largely effective in counteracting these trends.

The paper has also shown that the 1990s productivity surge sustained increases in real wages. But since higher wage rates were matched by higher productivity, there was no inducement for producers to substitute capital for labour. Indeed, with strong output growth, employment growth accompanied the real wage growth.

Wages and employment growth are both important, not only in determining the amount of income distributed to labour in aggregate, but also in influencing the distribution of income gains between those in and out of work. An important question - and one that has been exercising some academic economists - is whether wage and income measures can be introduced to promote additional employment growth, in order to make further inroads into unemployment.

The paper also points to the importance of competition. Competition is not only a driver of productivity growth, but it also provides incentives for productivity gains to be passed on to purchasers - with wider distributional consequences - rather than being retained within businesses in profit or wage growth.

\section{References}

Australian Bureau of Statistics (2001), Income Distribution 1999-2000, ABS Cat. no. 6523.0, AGPS, Canberra. 
Banks, G. (2001), 'Competition and the Public Interest', Speech to National Competition Council Workshop, 'The Public Interest Test Under National Competition Policy', Colonial Stadium, Melbourne, 12 July, available at:

http://www.pc.gov.au/research/speeches/cs120701.pdf.

Blanchard, O. (1997), 'The Medium Run', Brookings Papers on Economic Activity, no. 2, pp. 89-158.

de Laine, C., P. Laplagne and S. Stone (2000), The Increasing Demand for Skilled Workers in Australia: The Role of Technical Change, Productivity Commission Staff Research Paper, AusInfo, Canberra.

Industry Commission (1996), Reform and the Distribution of Income - an Economy-wide Approach, Staff Information Paper, AGPS, Canberra.

Kryger, T. 1999, 'Private Sector Executive Salaries', Parliamentary Library Research Note 24, 1998-99, available at: http://www.aph.gov.au/library/rn/1998-99/99rn24.htm (accessed 3 April 2000).

National Centre for Social and Economic Modelling (2000), 'Income Distribution Trends 1982 to 1996-97', report prepared for The Australian, available at: http://www.highered.theoz.com.au/flathtml/extra/where/data/trends.pdf (accessed 30 June 2000).

Norris, K. and B. McLean 1999, 'Changes in Earnings Inequality, 1975 to 1998', Australian Bulletin of Labour 25(1):23-31.

Organisation for Economic Co-operation and Development (2001), The New Economy: Beyond the Hype, Final Report on the OECD Growth Project, Executive Summary, OECD, Paris.

Parham, D., P. Barnes, P. Roberts, and S. Kennett (2000), Distribution of the Economic Gains of the 1990s, Productivity Commission Staff Research Paper, AusInfo, Canberra.

Parham, D. and S. Kennett (2001), Australia's Aggregate Productivity Performance to 1999-00, Productivity Commission Staff Research Paper (forthcoming).

Productivity Commission (1999), Microeconomic Reforms and Australian Productivity: Exploring the Links, Commission Research Paper, AusInfo, Canberra.

The authors are grateful for helpful comments from anonymous referees. The material in this article is based on and updates Parham et al. (2000). 